\title{
The Study of Conflict Victim Aggression at Poso Conflict Region
}

\author{
Muhammad Nur Ali \\ Tadulako University \\ Central Sulawesi, Indonesia \\ e-mail : muhammadnurali24@gmail.com
}

\begin{abstract}
The study of conflict victim aggression at Poso conflict region, Central Sulawesi Province studied the attack behaviour (attacking one another) among "actors-victims-new actors". The underlying decision of victims to do the aggression or attack as the way to revenge, was to attract attention and demand justice from the government. In fact, it made the condition worse because the targeted object was often obscure and directed to the substitutive object as the substitution, which caused new victims as the actor candidates. This vicious circle complexity has become an important factor in protracted conflict at Poso conflict region. The research result discovered that (1) aversive phenomena experienced by the conflict victims at Poso from the most dominant at the first cycle successively (i) pain and suffer, (ii) injustice treatment, and (iii) aspiration failure. At the second cycle and so forth which then forming conflict-chain, more dominated successively by (i) deprivation, (ii) aspiration failure, and (iii) injustice; (2) unfavourable experience or aversive of conflict effect, had disturbed mental and psychological stability of victim families and/or relatives, that had potential to do aggression to the parties considered actors; (3) the potential of aggressive behaviour at each victim individual was inseparable from the social frame of the surrounding groups and communities; (4) the situational response constituted the aggressing factor (brutal) which was generally not directed to the targeted object, but targeted to the substitutive target which would emerge new victims and problems. The fall of new victims as substitutive victims, as the consequence of the main target missing, initiating the emergence of new problem. The parties (substitutive victims), then did the aggression as the form of revenge. Such bad situation became worse because there was no preventive protection and security from the local government. The basis forming the causality of conflict victims at Poso region became so complex and might occur up to now.
\end{abstract}

Keywords- Aggression - Poso Conflict

\section{INTRODUCTION}

\section{Background}

The conflict in Poso began in the end of 1998 and last for ten years. The conflict, which was an open war $^{1}$ and popularly called Chapter $V$ Conflict popularly known

\footnotetext{
${ }^{1}$ It is called an open war because when there is mutually shooting among the different communities, the security service did not do any peace action to stop shooting each other. But according to the explanation of the local society, the security service at the moment, were the good watchers.
}

“Konflik Jilid V” (Lasahido et al, 2003) [14] changed into terrorism that last more and less seven years ${ }^{2}$. However, since January $11^{\text {th }} 2007$, the conflict, widely informed by the media, was known as Structural Conflict, the so popularly termed "Konflik Struktural", between the armedgroup people listed as wanted people or "Daftar Pencarian Orang” (DPO) according to the police, and the government.

Field observation or survey identifies the conflict as (1) a political conflict, the so termed "Konflik Elit Politik", because it took place during the regent election agenda; (2) an adolescent naughtiness among groups of young people, so popularly termed "Konflik Antar Remaja"; (3) an open war among different groups of citizens or community so called Horisontal Conflict or "Konflik Horisontal" in forms of kidnapping, shooting, bombing, and terror or a "like terrorism conflict"; and (4) mutually shooting between groups of people on one side and police on the other side. It is included as a structural conflict as mentioned above.

The war has caused so many people dead and countless possessions or properties lost ${ }^{3}$. The conflict had given bad experiences to many innocent people or families. It was then getting worse because the war was changed into revenge. A man or a family, the victim, can perform aggressively and endangers others even innocent families or people because of such brutal treatment other people do to them (Zillmann, 1989; Hall \& Lindzey, 2003; Berkowitz, 2003). [5] [9] The researcher observed that almost all people who were the victims found easily to do aggressive actions as responses or revenges. According to Bandura [2], (1999), socio-psychologically, a certain social situation such as provocation can trigger bad emotion or socio-psychological mechanism to endanger other people. In such condition, Goleman (1998) says that one's ratios do

\footnotetext{
2 On August $28^{\text {th }}$ 2008, one of the bombs exploded again in Sayo, and on October 21st 2008, three active bombs were found in Labuan village, Lage district bordered with Kaponda village, Poso Kota district. The actors of the actions were not known yet.

3 According to several members of society interviewed, their families and victims are tyrannized, even some were raped before they are killed, the property are rubbed without feeling innocent, their homes were burnt and were hauled. Some wre done in front of the security service (based on the result of interview limited to few people in Poso, on October $27^{\text {th }}$ to $\left.30^{\text {th }} 2006\right)$.
} 
not properly work that makes him or her easy to aggressively be brutal toward others. [8]

\section{Research Problems}

The following are a number of important aspects dealt with by this research: (1) aversive experiences such as deprivation, aspiration failure, injustice policies, feeling painful, and suffers; (2) internal phenomena and personal behaviors that lead to taking revenge to certain group of people; (3) triggering social environment; (4) dehumanization process towards other people identified or listed as the next victims; (5) any perspective that legitimates the aggressive behaviors of the actors; (6) the actor's resistance towards local government, local norms, and local conventions; and (7) any consideration in determining new targets including substitutions as revenge.

In relevance with the seven aspects presented, this research focuses on the following questions: (1) How is the quality of aversive experience of the victims in the conflict area in Poso? (2) How does the social environment trick or arrange next victims in the conflict area in Poso in such away that their socio-psychological mechanism becomes so aggressive? (3) How is the process of aggressive behaviors actualized as harshness or aggressive attack?

\section{B. CASE APPROACHES AND PREVIOUS RESEARCH RESULTS}

The aggressive action is more and less regarded as a kind of human behavour. It begins with cognitive process that forms a certain attitude to produce a certain action or aggression. So, the word aggression is concerned with ways of thinking, having acertain attitude, and taking an action (Ali, et al., 2017). [1] Many cases of aggression are in fact triggered by anger according to Malamuth, in Spier, et al. (1990). The cases are triggered by many factors identified as social-cultural, economical, political, ideological, as well as discriminations according to tribe, religion, and race, so popularly termed "SARA" (suku, agama, ras). Feeling being of the same tribe, same religion, and same race are very sensitive in the community and individuals.

If any type of aggression is because of frustration as said by Dollard in Spear, et al. (1990), any aversive experience is potential to motivate any individual to be an aggressor. The aggression behavior therefore is dependent on how an individual sees his past experiences or history and how he responds it (see Bandura, 1996). The aggression behavior and its aim is a part of behavior to devastate other people (Baron, 1987), [4] although the devastated side or victims are only the substitutions (see Spear, et al. 1990). [16] If seen from the view point of devastation it self, the aggression behavior is a serious effort performed to hurt other people (Berkowitz, 2003). Any aggression to hurt or to devastate other people (Baron, 1987) emphasizes four main components i.e. (1) human being is either an aggressor or a victim, (2) the action is a crime, (3) the aim is to cause any crime, (4) the victim is not the one who takes part in the problem, or he is only a substitution.

Based on the theoretical approach presented above, the conceptual abstraction or aggression construct can be seen as: (1) devastative actions acted by one or more people to hurt or to devastate other people, (2) the devastative actions are psychological because of aversive experiences, (3) being difficult to aim at the main target, the targets are directed to substitution objects.

Several research results relevant to this studied include a research founded on the model of CognitiveBehavioral-Therapy (Lochmann, et al 1993) finds that children and adults who behave aggressively suffer more from psychopathology that lead to do aggressive actions. [15] Another research finds that men of different ages find difficult to recall a sign, behave, social problem solution, self-esteem, and ways that support positive influence that they are not able to do, and maybe they experience it at different situations. Such condition is a situation that motivates an aggressive behavior to occur.

The model of Children's Appreciation Test (Henry, 1991) contends that the aggression desire that needs objective stimulus occurs at people who are always stimulated to cause enemies. This model shows that the children who are in habit to prejudice other children always show their feeling or character of being easy to cause or create enemies. [10]

The model of Cognitive-Behavioral Intervention by Dodge \& Lochmann (1998) contends that adolescents who behave aggressively are motivated by interpersonal signs that link behavior with desire to cause or create enemies. [6] The result of this research reports that adolescents have high aggression that makes them very sensitive. Those who have aversive experience tend to have high motivation to do aggression. This is indicated by the relatively young-aged people listed as "wanted people” in Poso. Their ages are over tens at the moment of their slaughter.

The model of Psychosocial Mechanism by Bandura (1996). Bandura says that aggressive actions by aggressors initiate by internal control release that is devastating. The process of Psychosocial Mechanism reported by social researches significantly strengthens the theory of Bandura in 1970s about the process of selfarrangement for moral losing while introducing action techniques for people prepared to do aggression (Bandura, 1996). The process intended covers: (a) reinterpreting the behaviors, (b) losing causes of actions, (c) distorting results, and (d) finding fault and underestimating targets. The assumption used are: (a) moral justification, (b) comparison of penalty that lightens, (c) labeling that softens, (d) minimizing, ignoring, or reinterpreting all consequences, (e) dehumanization, and (f) shifting fault and penalty.

\section{RESEARCH METHOD}

1. Research Design and Approach 
This study uses qualitative research design. All phenomena identified are explained by using abstractive inductive, a way of logical thinking to explain phenomena from specific to general cases (Faisal, 2003). [7].

The approach applied fulfills the need of descriptive analysis technique. The analysis technique applied is thought to have ability to explain in detail, because the study about the aggressive behavior has complex internal and external dimensions. This study therefore uses qualitative phenomenological approach leading to ethno-methodological approach. Besides, the study uses symbolic interaction (see Lincoln [11] \& Guba, 1985; Moleong, 2002 [13]; and Faisal, 2003). The judgments of the researcher about the aggression in this study are (1) as social fact of macro conflict evidence (society); (2) the conflict has resulted with many victims; and (3) the complex and long-way solution shows that the study deals with the authentic subjects, or nothing to do with the subjects in experiment studies. This is the reason why this study uses more than one approach.

\section{Research Focus}

This research is a kind of socio-psychological research oriented to aggression study or aggressive behavior towards the conflict victims. The research focus includes: (1) aversive experience including deprivation, aspiration failure, injustice, feeling painful, and suffer; (2) Social situation at the area of conflict, where the victims are conditioned to be aggressive or not; (3) The actualization of aggressive behavior in the conflict area in Poso is assumed as a way of taking revenge or asking for care from government/security service.

\section{Research Object and Subjects}

The object of this research is aggression or aggressive behavior towards the victims in the conflict area in Poso. The aggression concept refers to internal experience, attitude, and external condition of conflict victims and the process of psycho-sociological movement until it becomes an aggressive behavior.

Meanwhile, the research subjects are inhabitants who are the conflict victims including those, whose families or members of family died or get lost, those who experience physical defect, and those whose properties get lost. In short, the research subjects are the conflict victims in Poso. The subjects in ten areas were interviewed. The first interview is done to 28 informants. Based on the data 11 of the informants should be involved in the next or second interview. The third interview involved the 11 informants again. The interview stopped when the data were considered complete or satisfied to do analysis.

\section{Technique of Data Collection}

The data obtained from the field are categorized as primary and secondary data. The primary data were collected by means of observation and in-depth interview. The informants were the conflict victims. The researcher himself was also an instrument. As an instrument, he can benefit any opportunity in the field to obtain and elaborate any information considered important.

\section{Data Processing and data Analysis}

Principally, the data processing and data analysis follow the way proposed by Miles \& Huberman (1992), that is a dynamical process in the sense that the data collection, data process, and data analysis are conducted at the same time and repeated many times according to the steps followed and needed. Every interview is followed by its data processing and inter-space conclusion. When the sessions of the interview finished, an inter-space conclusion of an episode is drawn to have a guide for the next episode. As formerly said, the researcher himself is also an instrument. The interactive process proposed by Miles \& Huberman (1992) is shown by the following figure. [12]

Figure 1: The interactive data processing and data analysis

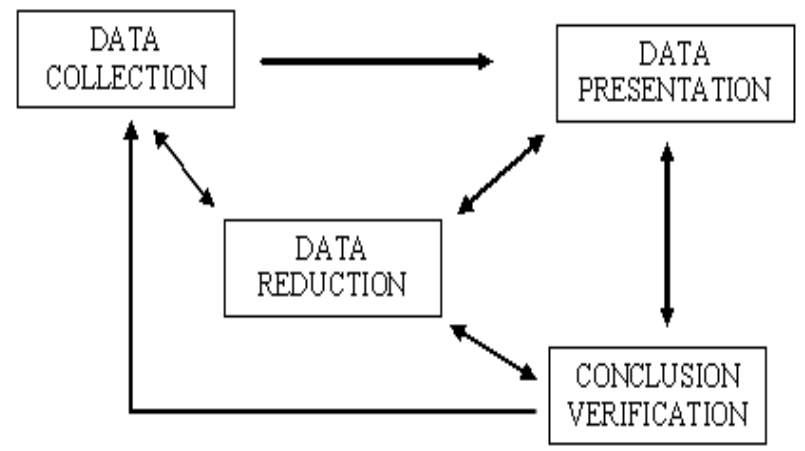

Source Miles \& Huberman (1992).

\section{RESEARCH FINDINGS}

\section{Aversive Phenomenon of Conflict Victims}

The conflict in Poso psychologically gives aversive unforgettable bitter memory to the victims. According to Zillmann (1989), [17] aversion deals with one's inconvenient experiences, like deprivation, aspiration failure, injustice, feeling painful, and suffer. The aversion of the victims as recorded in dialogue, where there are a number of victims still psychologically are unbalanced. Such kind of psychological condition is very sensitive and potential for a victim to do an aggressive action.

The kinds of aversion according to dialogue include deprivation, injustice, and suffer. If such inconvenient aversive experiences dominate emotions of the people victimized, the people are motivated to do actions that possibly can lead to damage other people, and then to endless new victims. It is prejudiced that these factors are the main causes of the conflict in Poso, that since ten years ago it has not been completely solved out yet. Dialogue shows the data about this and the real condition in Poso society up to the present ${ }^{4}$. The

\footnotetext{
${ }^{4}$ On August $28^{\text {th }} 2008$, one of the bombs exploded again in Sayo, and on October 21st 2008, three active bombs were found in Labuan village,
} 
community conflicts cannot be viewed only from face-toface physical collisions, but can also be viewed massively, that is by looking at latent movements occurring in the society.

The loss of property or possessions and principal right is expressed by the victims in the forms of unfriendly attitudes that lead to creating enemies motivated by aversive emotions.

The push of aversive emotions of the individuals who experienced bad impact of the conflict in Poso internally triggered by psychological condition seems externally strengthened by the less protection and less security of the local government during the open conflict. Such condition has stimulated the growth of negative responses including (1) a prejudice that they felt unprotected by the government, (2) disloyalty to on-going norms of law because of feeling unprotected. Such negative responses have made them handle over the problem by themselves by way of taking revenge. Taking revenge according to the victims is meant a warning as well as a lesson for the sides that are in fact the victims. The unfriendliness attitude of the victims is directed to individuals or sides or groups thought to be the aggression actors.

Psychical tension because of the aversion experienced by individuals usually aggressively responded if not avoided (see Berkowitz, 2003), in this research, tend to be more aggressive rather than to avoid. Based on what the information given by the informants, the aggressive responses by victims against the aversions of other people or sides are actualized in forms of actions to suffer them back. If the aggressive responses to an individual or groups in a society are dominant or so severe, there will be a back revenge.

\section{Situational Response}

This section discusses a social situation of individuals, groups, and society because of the conflict they faced. As has been formerly touched, the conflict in Poso has given unforgettable bad experiences for the victims. Moreover, if the condition is negatively responded, there will be a repetition of the same experience and could be a kind of continuous situational enforcement. The situational enforcement intended can be in form of internal solidarity in groups or community. It can also be an indirect on purpose permission of government or it may be a weakness on the side of law keepers.

The situational responses of the conflict victims in Poso are signaled by response expressions as said by informants. The similar collective responses expressed by groups or society can be seen as a factor that always gives enforcement as the actualization of aggressive behaviors. It seems that the social condition of the society where the victims live, collectively has legitimated destructive actions that can lead to conflict continuation or other new conflict

Lage district bordered with Kaponda village, Poso Kota district. The actors of the actions were not known yet. as informed. The constructive situational responses or preventive responses are not found in dialogues with the informants. The situational responses judged moderate are only the responses that state that the informants will not conduct aggressive actions, but their opinions about others show that they have different reasons but all implicitly justify it.

The psycho-sociological movement mechanism that can make an individual aggressive (see Bandura, 1996) initiates with a negative impression in an individual. The factor of social environment here holds an important role, where the social environment normatively has legitimated uninterested manner or attitude of individuals who are the victims to do a series of revenges. The situational responses of the social environment have made the aversive individuals lose their internal control. The internal loss of control intended deals with:

(a) making an interpretation that the aggression they experienced is purposely created especially by government that, according to the people in society, is a side who is responsible for the conflict. The responses of the society around the victims also agree with the aggressive actions by the victims, while seen from the side of religion the aggression the victims conducted is a spirit to do any aggression, although the charge is their souls.

(b) Getting the causes lost, i.e. from the feeling of private revenge because of aversion according to the version of religion. By being on behalf of religion they trust, the private revenge get lost, and it seems that their actions are the representation of the religion values ${ }^{5}$.

(c) Twisting the result (distortion) of all regulations or rules that will penalize them. All the results of positive law are put under or lower than the law of God. Meanwhile, the God's law is interpreted in such a way for the purpose of legitimate ${ }^{6}$.

(d) Underestimating the values of aggression by using value standard that its truth has been already justified before. Those who are believed to have caused other people become victims, are properly victimized by underestimating their existence among other people i.e. by deprivation and dehumanization. Such underestimation not only to main targets but also to those who are innocent regarded as substitution targets.

\section{Aggressive Behaviors of Conflict Victims}

The aversive phenomena experienced by the conflict victims in Poso and the situational responses

\footnotetext{
In the conflict society, the representation of the religious values by certain sides is well known as syahid or ready to die in God' will, and the allowed blood of Jesus.

${ }^{6}$ The interpretation of the religion values presented above is not just a justification to see what's wrong and what's right, but just the empirical fact presentation of the movement of psychological mechanism phenomenally.
} 
presented in the front lead to the boom of aggressive behaviors in order to take revenge or to give a lesson as a way of penalize someone. The aggressive behaviors such as bomb exploding, terror, shots, and even kidnapping are forms of taking revenges done by those who feel victimized. Any brutal action that endangers, damages, even kills other people are thought usual in the environment of victim society in Poso.

Besides to take revenge that can cause new victims, the aggressive behaviors are also to create endless new problems. The aggression as revenge is not a solution, but an addition to more complex problems, just like aggression in form of devastating substitutions. The result of data triangulation shows is a result of confronting transcript data and information from the sides who know well the aggression. The result shows that so little hit the main targets. Although the aggressions hit the targets, many other innocent people such as children and women can also be the victims. Based on the experiences of the victims, it can be explained that if the main targets are save from the aggressions conducted, the substitutions, that is, their close relatives of the actors are the targets.

The aggressive behaviors of the conflict victims as presented above are not only as the revenges but as actions in order to make other sides offended. The meaning of taking revenge widely shifts to uncontrolled actions, among others are (1) the victims are not the real targets, (2) the actions are crimes over crimes that create new problems, and (3) the actions result with more complicated problems that should be solved out for reconciliation.

The other side that has a link to the aggressive behaviors is that there is enforcement by means of external justification of social environment, and the passiveness of the government as the security keeper. The justification given by the social environment is the internal social environment initiated by a dichotomy in groups of social units. Each of the social units gives enforcement for the aggressive behaviors of the members of the groups agree, or at least by letting the ways of taking revenges occur. Claiming one another about the truth and blaming one another about the aggressive behaviors has raised as an issue very often coming into surface in the social groups in the conflict area in Poso. The internal responses of groups as actors clearly or unclearly give justification of the aggressive actions.

Meanwhile, from the other side, there is a chance seems to purposely be let by government believed as a security keeper. The less initiative of the local government to prevent from and anticipate any brutal actions is a condition that, according to any groups in society, it is purposely let by the government, and they consider it as the government's justification.

\section{Causality Netting: Victim-Aggression-Victim}

The repetition of aggressive behaviors by the second victims as the responses against the aggressive actions of the first actors called revenge or warning, is a series of aggressions potential to be endless. Initiating from the conflict victims that experienced aversion that causes them to be aggressors will cause new victims who are commonly substitution targets. It is because they found hard to aim at the main targets. That is the cycle of aggression in the conflict area in Poso.

The repetitions of the aggressive actions are just like an evil circle with no start and end. In this research, it is called "Causality Netting of Aggression of Conflict Victims in Poso". The data about the netting are obtained from dialogue. The dialogue shows that the first victims are sometimes angry and sad. The next reaction is blaming any sides or groups while identifying target candidates. The intensity of situational responses towards individuals starts to trigger actor candidates for new targets considered the right targets. The causality netting presented last cyclically as seen in figure 3 .

The social problem which is complex enough in society in Poso during the conflict season is less confidence towards sides that try to do reconciliation, particularly from the government and NGO, as well as towards important people in the society itself. The resistance of the society particularly of the victims to gain reconciliation is high enough. The program of reconciliation during the conflict season that experiences high resistance is "Reconciliation Program” by Ministry of people's Welfare and government of Province of Central Sulawesi that involves local society representatives or important people of the regency of Poso and certain. The individuals who have experienced aversion need intervened by performing socio-psychological approaches to reconcile their mental and personality that have been degraded.

\section{E. CONCLUSION}

The following are the main ideas drawn as conclusions based on the results of data analysis of this research.

1. The aversive phenomena experienced by the conflict victims in Poso are presented according the degree of dominance in the first cycle are respectfully (1) feeling painful and suffer (2) injustice treatment, and (3) aspiration failure. Meanwhile, in the second cycle, and so on, it is dominated by respectfully (1) deprivation, (2) aspiration failure, and (3) injustice.

2. The inconvenient experience or the aversion because of conflict has disturbed stability of psychological mental of the close family or relatives of the victims, so the experience is potential to do aggressive actions towards sides or groups considered to have made the families or relatives victims.

3. The power of aggressive behaviors of every individual victim is inseparable from the structure of social groups and society. The situational responses are factors that sometimes trigger brutal aggression that many times cannot hit the targets 
except the substitutions that can lead to new victims and or new cases

4. The new victims as substitution victims because of missing the main targets initiates new cases or problem to occur. The substitution victims certainly make plan to do revenge. Such condition is becoming worse by the less protection and preventive security on the part of the local government. This is the start of causality netting of conflict victims in Poso, and now it turns to very complex case.

5. It needs to do intervention to change the aggressive behaviors if all sides want to stop the conflict. Any psychological consideration however, can reconcile the aversive phenomenon of the victims. Further, any sociological diagnose is done to change the responses of local society which is very proactive to aversive individuals into reconciliation and cooperation through mutual trust-building.

\section{REFERENCES}

[1] Ali, M.N., Emrizal, Razman, M.R., Ramli, Z., Arifin, Z. 2017. Understanding Aggressive Behaviour to Avoid Demages Through the Precautionery Principle Towards the Sustainable Development Goals (SDGs). Journal of Food, Agriculture \& Environment 15(1): 52-55.

[2] Bandura, A. (1996). Social Foundations of Thought and Action: A Social Cognitive Theory, Englewood Cliffs, N.J.: Prentice-Hall.

[3] Baron, R.A. (1987). Human Aggression, New York: Plenum.

[4] Berkowitz, L. (2003). Aggression: Its Causes, Concequences, and Control. New York: Mc.Graw Hill Inc

[5] Dodge, K.A., \& Lochmann, J.E. (1998). Social-Cognitive Processes of Severely Violent, Moderately Aggressive, and Nonaggressive Boys, dalam: Journal of Counseling and Clinical Psychology, Vol.62, No.2, p.366-374.

[6] Faisal, Sanapiah. 2003. "Filosofi dan Akar Tradisi Penelitian Kualitatif”. Dalam: Burhan Bungin (Ed.). 2003. Analisis Data Penelitian Kualitatif, Jakarta: Rajawali Press.

[7] Goleman, D. (1998). Emotional Intelligence: Why it can Matter More than IQ. New York: Bantam Books

[8] Hall, C.S. \& Lindzey, G. (2003). Teori-Teori Psikodinamik (Klinis), Supratiknya (ed), Yogyakarta: Kanisius.

[9] Henry, R.M. (1991). Validation of a Projective Measure of Aggression-Anxiety for Five-Year-Old Boys, dalam: Journal of Personality Assesment, Vol.45, No.4, p.359-369.

[10] Lincoln, Y.S. \& Guba, E.G. 1985. Naturalistic Inquiry. Beverly Hills: Sage Publication.

[11] Milles, M.B \& Huberman A.M. 1992. Analisis Data Kualitatif, Tjetjep, R.R (Penerjemah), Jakarta: Universitas Indonesia Press.

[12] Moleong, L.J. 2002. Metodologi Penelitian Kualitatif. Bandung: Remaja Rosda Karya

[13] Lasahido, T. Dkk. (2003). Suara Dari Poso: Kerusuhan, Konflik, dan Resolusi. Jakarta: YAPPIKA.

[14] Lochmann, J.E., Coie, J.D., Underwood, M.K., \& Terry, R. (1993). Effectiveness of a Social Relations Intervention Program for Aggressive and Nonaggressive, Rejected Children, dalam: Journal of Counseling and Clinical Psychology, Vol.61, No.6, p.1053-1058.

[15] Spear, P.D., Penrod \& Baker. (1990). Psychology: Perspectives on Behavior, New York: John Wiley \& Sons.

[16] Zillmann, D. (1989). Hostility and Agression. N.J Erlbaum: Hillsdale. 